\title{
Effect of Fennel and Dill Seeds on Serum Lipid Profiles of Rats Feeding High Fat Diet
}

\author{
Wafaa A. Refaat $^{1}$ and Doaa E. El-Nassag ${ }^{2}$
}

${ }^{1}$ Department of Nutrition and Food Science, Faculty of Home Economics, Menoufia University, Egypt

${ }^{2}$ Department of Home Economics, Faculty of Specific Education, Alexandria University, Egypt

\section{Abstract:}

$\mathrm{D}$

ill and fennel seeds are herbal plants cultivated in various regions worldwide; they have many therapeutic effects such as anti-inflammatory, antibacterial, antiviral, anti-hyperlipidemia and antidiabetic. Therefore, this

study was conducted to examine the effect of fennel and dill seeds powder on serum lipid profile of rats feeding high fat diet. Forty adult male albino rats weighting (200 $\pm 7 \mathrm{~g}$ ) were divided into eight equal groups of 5 animals each, one was kept as a control $(-\mathrm{Ve})$ group, while the other 7 groups were fed on high fat diet (HFD), group (2) were left as a control $(+\mathrm{Ve})$ fed on HFD only all experiment period (28 days), groups $(3,4)$ fed on HFD $+2.5 \%$ and $5 \%$ of dill seeds, respectively, while groups $(5,6)$ fed on HFD+ $2.5 \%$ and $5 \%$ of fennel seeds, respectively, the last groups $(7,8)$ fed on dill and fennel seeds mix $(50 / 50 \mathrm{w} / \mathrm{w})$ with $2.5 \%$ and $5 \%$, respectively. At the end of experiment serum glucose level, liver enzymes activities, kidney functions and lipid profile were examined. The results indicated that the increase of fennel seeds or dill seeds concentration resulted in reduction of serum glucose level and significant $(p \leq 0.05)$ decreased serum very low-density lipoprotein (VLDL), low density lipoprotein (LDL), triglyceride and cholesterol. Also, the results revealed that fennel seeds have a better effect than dill seeds on high density lipoprotein (HDL) level. Treatment with fennel seeds or dill seeds at different levels caused significant $(\mathrm{p} \leq 0.05)$ decreased uric acid, creatinine and urea levels compared to positive control group. The results also revealed there no significant differences between the groups in albumin level. There was a significant $(\mathrm{p} \leq 0.05)$ decrease in the activities of alanine aminotransferase (ALT) and aspartate aminotransferase (AST) of fennel seeds and dill seeds groups compared to positive control group. Therefore, the present study concluded that fennel and dill seeds powder could be used into daily foods and beverages as hypo-lipidemic herbs.

Key words: Dill, Fennel, Seeds, Serum lipid profile, albumin, liver enzymes activities

\section{Introduction}

Hyperlipidemia greatly increases the development of coronary heart disease and arteriosclerosis. Worldwide atherosclerosis is the most 
common cause of death (Marzyieh et al., 2007) Development of heart disease is caused by hyperlipidemia due to high cholesterol diet. In civilized societies; ischemic stress of the heart is the major cause of death (Hexeberg et al., 1993). Although numerous factors, such as family history, age, life style, hypertension and diet high in cholesterol and saturated fats play a significant role leading to heart failure, the high levels of cholesterol particularly triglyceride, low LDL-C and total cholesterol is mostly responsible for the start of cardiovascular diseases (Marzyieh et al., 2007). The use of herbs and different parts of plants to treat diseases has been common since ancient times in public health. Using herbal medicines and natural remedies is beneficial cost-effective method for treating diseases (Ghasemi Pirbalouti, 2009); (Tang and Halliwell, 2010).

Among these herbs can point to fennel (Foeniculum vulgare Mill) which is of great importance and is used in the food, pharmaceutical, healthcare industries and cosmetic (Abe and Ohtani, 2013). Fennel is one of the oldest spice plants which widely grow in arid and semi-arid. The stalk, seeds and leaves are edible part (Cosge et al., 2008). It is one of the world's most medicinal herbs based on pharmaceutical industry usage and economic importance (Jamshidi $\boldsymbol{e t}$ al., 2012). Since ancient times, fennel seeds have been known as aromatic and medicinal herbs, widely used in the flavor of fish, bread, cheese and salads (Kaur and Arora , 2010). This herb contains phenolic compounds such as phenolic acids, flavonoids, coumarin, tannin and hydroxycinnamic acids (Rahimi and Ardekani, 2013).

Recently, fennel seeds were found to have possess pain reliever in primary dysmenorrhoea (Modaress and Asadipour, 2006), antidementia (Joshi and Parle, 2006), antispasmodic activities (Ostad et al., 2001), a hypotensive effect (EI Bardai, 2001), antiplatelet and antithrombotic (Tognolini et al., 2007), anticancer (Celik and Isik, 2008), antioxidant (Barros et al., 2009), hepatoprotective (Ozbek et al., 2003), antihirsutism 
(Javidnia et al., 2003), anti-inflammatory (Choi and Hwang, 2004), immunomodulatory (Kaileh et al., 2007) and potential in the treatment of glaucoma (Celik and Isik, 2008). Fennel herb could be used for controlling cardiovascular disorders (Oulmouden et al., 2014).

Dill with the scientific name of Anethum graveolens is a plant from the Apiaceae family, having quercetin and flavonoids such as coumarin, vicenin, kaempferol and myristicin that are known phytoestrogens (Monsefi and Gramifar, 2013). In traditional medicine, dill is used as an antiseptic, relieve bloating, stomach tonic, indigestion, carminative, antivomiting and spasms, laxative, reducing blood lipids and pain soothing (Setorki et al., 2013). Dill has pharmacological effects such as cancer chemo-preventive effects (Zheng et al., 1992), antibacterial activity (Delaquis et al., 2002), antihypercholesterolemic and antihyperlipidemic effects (Yazdanparast and Alavi, 2001). Therefore, the present study aimed to examine the effect of fennel and dill seeds on serum lipid profile of rats feeding high fat diet.

\section{Materials and Methods}

\subsection{Materials}

Fennel and dill seeds were purchased from Agricultural Seed, Spices and Medicinal Plants Co. (Harras), Cairo, Egypt.

\subsection{Chemicals and solvents}

All chemicals and solvents were analytical grade; vitamin and salt mixtures components used for rats feeding were purchased from TechnoGene, Chemical Co., El Doki, Egypt. Casein was obtained from Morgan Chemical Co., Cairo, Egypt. 


\subsection{Animals}

Forty adult male albino rats, weighting $(200 \pm 7 \mathrm{~g})$ were purchased from Research Institute of Ophthalmology, Medical Analysis Department, Giza, Egypt. Rats were housed ( 2 per cage) and maintained on a12 h light: $12 \mathrm{~h}$ dark cycle in a temperature $(20 \pm 5)$ and humidity- controlled atmosphere and were fed on standard diet for one week to acclimatize at animal research laboratory, Faculty of Home Economics, Menoufia University, Egypt.

\subsection{Methods}

\subsubsection{Plant parts preparation}

Fennel and dill seeds were powdered by electric grinder (Moulinex, France) and kept stored at $4{ }^{\circ} \mathrm{C}$ until used.

\subsubsection{Basal diet}

The basic diet prepared according to the following formula as mentioned by AIN (1993) as follow: protein (10\%), corn oil (10\%), vitamins mixture (1\%), mineral mixture (4\%), choline chloride $(0.2 \%)$, methionine $(0.3 \%)$, cellulose $(5 \%)$, and the remained is corn starch (69.5\%). The used vitamin mixture component was that recommended by Campbell (1963) while the salts mixture used was formulated according to Hegsted et al. (1941).

\subsubsection{High fat diet}

The composition and preparation of high fat diet as were described by Reed et al., (2000).

\subsubsection{Biological experimental design}

Rats were divided into eight equal groups of 5 animals each, one was kept as a control(-Ve) group, while the other 7 groups were fed on high fat diet (HFD), group (2) were left as a control (+Ve) fed on HFD only all experiment period (28 days), groups $(3,4)$ fed on HFD+ $2.5 \%$ and $5 \%$ of dill seeds, respectively while groups $(5,6)$ fed on HFD+ $2.5 \%$ and $5 \%$ of fennel 
seeds respectively, the last groups $(7,8)$ fed on dill and fennel seeds mix $(50 / 50 \mathrm{w} / \mathrm{w})$ with $2.5 \%$ and $5 \%$, respectively. At the end of experiment serum glucose level, liver enzymes activities, kidney functions and lipid profiles were examined.

\subsubsection{Blood collection}

After 4 weeks, blood was obtained via heart puncture after an overnight fasting; rats were anesthetized with diethyl ether. Blood samples were collected into a dry clean centrifuge glass tubes. Serum was separated by centrifugation at $4000 \mathrm{rpm}$ for 15 minutes at room temperature .Serum was carefully aspirated and transferred into clean cuvette tubes and kept frozen at $\left(-20^{\circ} \mathrm{C}\right)$ until analysis (Malhotra, 2003).

\subsubsection{Biochemical analysis}

Different tested parameters in serum were determined using specific methods as follow: Serum glucose was estimated according to Rojas et al. (1999). Urea and creatinine levels were determined in serum according to the method described by Houot (1985). Serum total cholesterol, triglyceride (TG) and high density lipoprotein (HDL-c) were determined by using methods of Allain et al. (1974), Fossati and Prencip (1982) and Lopez-virella (1977), respectively. The determination of low density lipoprotein cholesterol (LDLc) and very low density lipoprotein cholesterol (VLDLc) were carried out according to the methods of Lee and Nieman (1996). Serum alanine aminotransferase (ALT) and aspartate aminotransferase (AST) were assayed by the methods of Moss and Herderson (1999).

\subsubsection{Statistical analysis}

The data were statistically analyzed using a computerized cost at program by one-way ANOVA. The results are presented as mean \pm SD. Differences between treatments at $\mathrm{p} \leq 0.05$ were considered significant. 


\section{Results}

\subsection{Effect of fennel and dill seeds at different levels on serum glucose level of rats feeding high fat diet}

Serum glucose level of rats treated with fennel and dill seeds at different levels are tabulated in Table (1). Data indicated that treatment with either fennel seeds or dill seeds resulted in significant $(\mathrm{p} \leq 0.05)$ decrease in serum glucose level compared to negative control and positive control groups. It's clear from the table that the increasing of fennel seeds or dill seeds concentration resulted in reduction of serum glucose level. Also, the table revealed that dill seeds have a better effect than fennel seeds on serum glucose level. It is observed from the table that mixture of fennel seeds with dill seeds at different levels showed significant $(\mathrm{p} \leq 0.05)$ lower serum glucose level than negative control or positive control groups.

Table (1): Effect of fennel and dill seeds at different levels on serum blood glucose level of rats feeding high fat diet

\begin{tabular}{|l|c|}
\hline \hline \multicolumn{1}{|c|}{ Groups } & Garameter \\
\hline Negative control & $185.3^{\mathrm{b}} \pm 3.51$ \\
\hline Positive control & $211.3^{\mathrm{a}} \pm 3.21$ \\
\hline Dill seeds 2.5\% & $120.8^{\mathrm{e}} \pm 3.82$ \\
\hline Dill seeds 5\% & $105.8^{\mathrm{f}} \pm 3.55$ \\
\hline Fennel seeds 2.5\% & $161.0^{\mathrm{c}} \pm 3.61$ \\
\hline Fennel seeds 5\% & $157.7^{\mathrm{c}} \pm 2.52$ \\
\hline Fennel \&dill seeds mix 2.5\% & $146.5^{\mathrm{d}} \pm 3.97$ \\
\hline Fennel \&dill seeds mix 5\% & $143.3^{\mathrm{d}} \pm 2.08$ \\
\hline \multicolumn{1}{|c|}{ LSD } & 5.781 \\
\hline \hline
\end{tabular}

Values are expressed as means $\pm \mathrm{SD}$; mean in the same raw with different letters are significantly different at $\mathrm{P} \leq 0.05$. 


\subsection{Effect of fennel and dill seeds at different levels on serum lipid profile of rats feeding high fat diet}

Lipid profile was determined in serum of male rats treated with fennel and dill seeds at different levels and the data are shown in Table (2). Data revealed that treatment with fennel and dill seeds significantly $(\mathrm{p} \leq 0.05)$ decreased serum very low-density lipoprotein (VLDL), low-density lipoprotein (LDL), triglyceride (TG) and cholesterol, while increased highdensity lipoprotein (HDL) compared to positive control group. It's observed from the table that the increasing of fennel seeds or dill seeds concentration resulted in significant $(p \leq 0.05)$ decreased of serum VLDL, LDL, triglycride and cholesterol. Also, the table revealed that fennel seeds have a better effect than dill seeds on HDL level. It's clear from the table that mixture of fennel seeds with dill seeds at $5 \%$ of mixture group resulted in significant $(p \leq 0.05)$ enhanced the level of HDL and decrease the levels of VLDL, triglyceride and cholesterol compared to $2.5 \%$ mixture group. It is concluded that high fat diet supplemented with dill and fennel seeds at different levels significantly $(\mathrm{p} \leq 0.05)$ decreased serum levels of cholesterol, LDL-C, VLDL-C and triglyceride, and significantly $(\mathrm{p} \leq 0.05)$ increased serum HDL-C level compared with feeding rats with high fat diet.

Table (2): Effect of fennel and dill seeds at different levels on serum lipid profile of rats feeding high fat diet

\begin{tabular}{||l|c|c|c|c|c||}
\hline \hline parameters & $\begin{array}{c}\text { VLDL } \\
(\mathrm{mg} / \mathrm{dl})\end{array}$ & $\begin{array}{c}\text { LDL } \\
(\mathrm{mg} / \mathrm{dl})\end{array}$ & $\begin{array}{c}\text { HDL } \\
(\mathrm{mg} / \mathrm{dl})\end{array}$ & $\begin{array}{c}\text { T.G } \\
(\mathrm{mg} / \mathrm{dl})\end{array}$ & $\begin{array}{c}\text { T.C } \\
(\mathrm{mg} / \mathrm{dl})\end{array}$ \\
\hline Negative control & $21.23^{\mathrm{c}} \pm 2.41$ & $64.07^{\mathrm{e}} \pm 2.32$ & $37.33^{\mathrm{b}} \pm 3.21$ & $114.7^{\mathrm{d}} \pm 2.08$ & $123.0^{\mathrm{d}} \pm 3.61$ \\
\hline Positive control & $41.73^{\mathrm{a}} \pm 2.48$ & $95.67^{\mathrm{a}} \pm 3.21$ & $37.33^{\mathrm{b}} \pm 2.08$ & $165.3^{\mathrm{a}} \pm 3.06$ & $162.7^{\mathrm{a}} \pm 2.31$ \\
\hline Dill seeds 2.5\% & $27.30^{\mathrm{b}} \pm 2.17$ & $65.90^{\mathrm{c}} \pm 3.60$ & $37.33^{\mathrm{b}} \pm 2.52$ & $135.3^{\mathrm{b}} \pm 3.51$ & $123.3^{\mathrm{d}} \pm 3.79$ \\
\hline Dill seeds 5\% & $16.67^{\mathrm{d}} \pm 2.05$ & $40.80^{\mathrm{e}} \pm 2.40$ & $37.33^{\mathrm{b}} \pm 2.08$ & $93.3^{\mathrm{e}} \pm 2.31$ & $102.3^{\mathrm{e}} \pm 3.21$ \\
\hline Fennel seeds 2.5\% & $27.90^{\mathrm{b}} \pm 3.30$ & $64.88^{\mathrm{c}} \pm 3.99$ & $46.0^{\mathrm{a}} \pm 2.0$ & $140.0^{\mathrm{b}} \pm 3.61$ & $140.0^{\mathrm{b}} \pm 2.65$ \\
\hline Fennel seeds 5\% & $22.60^{\mathrm{c}} \pm 2.11$ & $52.70^{\mathrm{d}} \pm 2.70$ & $45.33^{\mathrm{a}} \pm 3.79$ & $123.7^{\mathrm{c}} \pm 3.21$ & $132.7^{\mathrm{c}} \pm 3.56$ \\
\hline $\begin{array}{l}\text { Fennel \&dill seeds } \\
\text { mix 2.5\% }\end{array}$ & $27.63^{\mathrm{b}} \pm 2.75$ & $73.17^{\mathrm{b}} \pm 3.41$ & $41.0^{\mathrm{ab}} \pm 3.46$ & $129.0^{\mathrm{c}} \pm 3.95$ & $141.3^{\mathrm{b}} \pm 2.08$ \\
\hline $\begin{array}{l}\text { Fennel \&dill seeds } \\
\text { mix 5\% }\end{array}$ & $16.30^{\mathrm{d}} \pm 2.50$ & $62.43^{\mathrm{c}} \pm 2.42$ & $44.67^{\mathrm{a}} \pm 3.79$ & $111.0^{\mathrm{d}} \pm 2.65$ & $137.3^{\mathrm{bc}} \pm 2.52$ \\
\hline \multicolumn{1}{|c|}{ LSD } & 4.330 & 5.303 & 5.120 & 5.379 & 5.241 \\
\hline
\end{tabular}

Values are expressed as means $\pm \mathrm{SD}$; mean in the same raw with different letters are significantly different at $\mathrm{P} \leq$ 0.05. T.C: Total cholesterol; T.G; Triglycerides; HDL: High density lipoprotein; LDL: Low density lipoprotein; VLDL: Very Low density lipoprotein. 


\subsection{Effect of fennel and dill seeds at different levels on uric acid, creatinine and urea of rats feeding high fat diet}

Effects of fennel and dill seeds at different levels on uric acid, creatinine and urea of rats feeding high fat diet were determined and the data are tabulated in Table (3). Data showed that treatment with fennel seeds or dill seeds at different levels caused significant $(p \leq 0.05)$ decrease in uric acid, creatinine and urea levels compared to positive control group. In the mixture group at level of 5\% fennel seeds with dill seeds resulted in significant $(\mathrm{p} \leq 0.05)$ decrease in uric acid, creatinine and urea levels compared to positive control group.

Table (3): Effect of fennel and dill seeds at different levels on uric acid, creatinine and urea of rats feeding high fat diet

\begin{tabular}{|c|c|c|c|}
\hline \begin{tabular}{|ll} 
Groups & Parameters \\
\end{tabular} & $\begin{array}{c}\text { UA } \\
(\mathrm{ml} / \mathrm{dl})\end{array}$ & $\begin{array}{l}\text { Creatinine } \\
(\mathrm{ml} / \mathrm{dl})\end{array}$ & $\begin{array}{l}\text { Urea } \\
(\mathrm{ml} / \mathrm{dl})\end{array}$ \\
\hline Negative control & $4.40^{b} \pm 0.62$ & $0.60^{\mathrm{ab}} \pm 0.05$ & $24.50^{\mathrm{a}} \pm 1.80$ \\
\hline Positive control & $5.43^{\mathrm{a}} \pm 0.15$ & $0.63^{\mathrm{a}} \pm 0.09$ & $24.67^{\mathrm{a}} \pm 1.53$ \\
\hline Dill seeds $2.5 \%$ & $3.32^{\mathrm{cd}} \pm 0.75$ & $0.51^{b} \pm 0.03$ & $23.33^{\mathrm{ab}} \pm 1.53$ \\
\hline Dill seeds 5\% & $3.02^{\mathrm{d}} \pm 0.62$ & $0.56^{\mathrm{ab}} \pm 0.07$ & $21.0^{\mathrm{b}} \pm 1.73$ \\
\hline Fennel seeds $2.5 \%$ & $3.87^{\mathrm{bcd}} \pm 0.25$ & $0.57^{\mathrm{ab}} \pm 0.04$ & $17.67^{\mathrm{C}} \pm 1.53$ \\
\hline Fennel seeds 5\% & $3.80^{\mathrm{bcd}} \pm 0.36$ & $0.59^{\mathrm{ab}} \pm 0.05$ & $23.70^{\mathrm{ab}} \pm 1.47$ \\
\hline Fennel \&dill seeds mix $2.5 \%$ & $4.13^{b c} \pm 0.32$ & $0.63^{\mathrm{a}} \pm 0.04$ & $24.0^{\mathrm{ab}} \pm 2.65$ \\
\hline Fennel \&dill seeds mix 5\% & $3.80^{\mathrm{bcd}} \pm 0.72$ & $0.56^{\mathrm{ab}} \pm 0.11$ & $23.33^{\mathrm{ab}} \pm 1.53$ \\
\hline LSD & 0.903 & 0.108 & 3.045 \\
\hline
\end{tabular}

Values are expressed as means \pm SD; mean in the same raw with different letters are significantly different at $\mathrm{P} \leq 0.05$, UA: Uric acid.

\subsection{Effect of fennel and dill seeds at different levels on albumin level and ALT and AST activities of rats feeding high fat diet}

Table (4) indicated the effect of fennel and dill seeds at different levels on albumin level, alanine aminotransferase (ALT) and aspartate aminotransferase (AST) activities of rats feeding high fat diet. The table showed that treatment with fennel and dill seeds caused increase in albumin 
level compared to positive control group. There no significant differences between the groups in albumin level. Also, it was observed that the activities of ALT of fennel and dill seeds groups showed significant $(\mathrm{p} \leq 0.05)$ decreased compared to positive control group. In the same line, the activities of AST of fennel and dill seeds groups resulted in significant $(\mathrm{p} \leq 0.05)$ decreased compared to positive control group. It is observed that there was significant $(\mathrm{p} \leq 0.05)$ difference between mixture groups at different levels and positive control group in ALT and AST activities. It's observed from the table that the increasing of fennel seeds or dill seeds concentration resulted in significant $(\mathrm{p} \leq 0.05)$ decreased of ALT and AST activities. Also, it's clear from the table that high level of dill and fennel $(5 \%)$ in mixture groups resulted in lower the activities of ALT and AST than low level of dill and fennel (2.5\%).

Table (4): Effect of fennel and dill seeds at different levels on albumin (ALB) level, alanine aminotransferase (ALT) and aspartate aminotransferase (AST) activities of rats feeding high fat diet

\begin{tabular}{||l|c|c|c||}
\hline \hline \multicolumn{1}{|c|}{ Parameters } & $\begin{array}{c}\text { ALB } \\
(\mathrm{g} / \mathrm{dl})\end{array}$ & $\begin{array}{c}\text { ALT } \\
(\mathrm{U} / \mathrm{L})\end{array}$ & $\begin{array}{c}\text { AST } \\
(\mathrm{U} / \mathrm{L})\end{array}$ \\
\hline Negative control & $3.59^{\mathrm{a}} \pm 0.49$ & $175.7^{\mathrm{b}} \pm 3.06$ & $186.7^{\mathrm{a}} \pm 2.08$ \\
\hline Positive control & $3.42^{\mathrm{a}} \pm 0.25$ & $190.0^{\mathrm{a}} \pm 3.61$ & $186.3^{\mathrm{ab}} \pm 2.52$ \\
\hline Dill seeds 2.5\% & $3.58^{\mathrm{a}} \pm 0.50$ & $175.3^{\mathrm{b}} \pm 2.08$ & $186.7^{\mathrm{a}} \pm 2.08$ \\
\hline Dill seeds 5\% & $3.59^{\mathrm{a}} \pm 0.47$ & $153.0^{\mathrm{c}} \pm 3.61$ & $182.0^{\mathrm{b}} \pm 3.61$ \\
\hline Fennel seeds 2.5\% & $3.58^{\mathrm{a}} \pm 0.19$ & $148.0^{\mathrm{cd}} \pm 3.61$ & $163.7^{\mathrm{d}} \pm 2.52$ \\
\hline Fennel seeds 5\% & $3.59^{\mathrm{a}} \pm 0.48$ & $141.7^{\mathrm{e}} \pm 3.51$ & $162.3^{\mathrm{d}} \pm 2.08$ \\
\hline Fennel \&dill seeds mix 2.5\% & $3.87^{\mathrm{a}} \pm 0.18$ & $153.3^{\mathrm{c}} \pm 3.06$ & $172.3^{\mathrm{c}} \pm 3.21$ \\
\hline Fennel \&dill seeds mix 5\% & $4.09^{\mathrm{a}} \pm 0.37$ & $143.0^{\mathrm{de}} \pm 2.0$ & $140.3^{\mathrm{e}} \pm 2.08$ \\
\hline \multicolumn{1}{|c|}{ LSD } & 0.674 & 5.416 & 4.469 \\
\hline
\end{tabular}

Values are expressed as means $\pm \mathrm{SD}$; mean in the same raw with different letters are significantly different at $\mathrm{P} \leq 0.05$. ALB: Albumin; ALT: Alanineaminotransferase; AST: Aspartateaminotransferase.

\section{Discussion}

The obtained result of serum glucose level of fennel groups is consistent with the previous study by Abou El-Soud et al. (2011) who observed that there was a reduction in serum glucose level in diabetic rats 
treated with essentiall oil of Foeniculum vulgare Mill. Fennel seeds contain from $3 \%$ to $6 \%$ of an essential oil and about $20 \%$ of a fixed oil composed of tocopherols, oleic acid and petroselinic acid (Conforti et al., 2006). Fennel oil possessed antioxidant, pro-oxidant activities and antiinflamatory (Miguel et $\boldsymbol{a l}$., 2010). The obtained result of lipid profile of fennel groups is agreement with earlier findings by Helal et al. (2011) and Dongare et al. (2012) who mentioned that the use of fennel might be effective for improving lipid profile.

Delaram et al. (2011) reported that fennel oil extracted has capability to suppress lipid peroxidation due to antioxidant properties; also it has a protective excessive fat degradation, inflammation and toxicity. The obtained result of serum creatinine, urea and uric acid in fennel groups is agreement with previous report by Alsalame et al. (2018) who concluded that there was a significant decrease $(p \leq 0.05)$ in the level of serum creatinine, urea and uric acid concentration of rabbits treated with alcoholic extract of fennel seed compared to cisplatin group.

Ayman et al. (2006) mentioned that the increase in uric acid might be disturbance or a dysfunction of the renal function as the results of the kidney damage, which led to necrosis in the renal tubules. The obtained result of serum uric acid of rats treated with fennel seeds is consistent with the previous finding by Fan et al. (1999) who concluded that the fennel seeds extract has a preventive role that prevents the formation of calcium oxalate crystals due to it contains efficient compounds such as flavonoids and phenols. Ibrahim and El-Khateeb (2013) reported that fennel seeds might have a protective activity of the kidney through decreasing damage to the cells of the urinary tubules led to reducing the level of uric acid.

Valko et al. (2007) mentioned that fennel plant has ability to decrease uric acid because it is contains a high amount of antioxidants. It is rich in ascorbic acid, alpha-tocopherol, has anti-inflammatory effects and acts as a diuretic. Choi and Hwang (2004) reported that fennel plant 
contains the active plant estrogen constituents which have ability to be diuretic and has a protective effect on the glomeruli led to reduce the symptoms of renal injury. Also, Bekhradi (2004) concluded that fennel seeds contain active compounds, which have anti-oxidant and antiinflammatory properties.

The obtained result of liver enzymes activities and albumin level in fennel groups is agreement with previous findings by Qiang et al. (2011) who observed that a significant decreased in AST and ALT activities and increased albumin (ALB) level in rats with hepatic fibrosis after fennel consumption. Liu et al. (2009) concluded that fennel might reduce inflammation in the liver and protect hepatocytes against liver damage. Also, Mannaa et al. (2015) indicated that fennel seed extract could significantly decrease serum AST and ALT due to hepato protective activity.

Jana and Shekhawat (2010) concluded that use the extractions of dill seed and leaf led to reduction in total cholesterol, very-low-density lipoprotein, low-density lipoprotein, triglycerides and glucose level, while HDL-C was increased and confirmed that dill has hypoglycemic and antioxidant activity. The antioxidant activity of dill is attributed to its phenolic proanthocyanidins and flavonoids constituents (Yazdanparast and Bahramikia, 2008). The main mechanism by which dill exerts its antidiabetic functions is inhibition of intestinal cholesterol absorption and increasing production of bile acids (Jana and Shekhawa, 2010).

The obtained result of serum cholesterol and triglycerides in dill groups is consistent with the previous report by Yousofvand and Soltany (2015) who concluded that the high concentration of dill extract (500 mg / lit) cause lower cholesterol and triglycerides level than low concentration (250 mg / lit), while in high concentration revealed a significant increase in high-density lipoprotein level. Yazdanparast and Alavi (2000) suggested that dill contains limonene, carvone and $\alpha$-phellandrene which responsible for the hypolipidemic properties. 
Kazemi et al. (2006) observed that there was a reduction in lipid profile, liver enzymes and inflammatory cytokines of New Zealand male rabbits treated with dill. Also, Kojuri et al. (2007) concluded that dill can be used as one of the most effective drugs in the treatment of hyperlipidemia in human. Monsefi and Gramifar (2013) reported that dill is rich source of antioxidants; it is contain quercetin and flavonoids. Antioxidant activity might be serum lipids-lowering agent. Ahmed et al. (2013) concluded that dill hydroalcoholic extract caused significant increase the level of HDL and decrease the level of triglycerides, total cholesterol, VLDL and LDL. Yazdanparast and Bahramikia (2007) confirmed that crude extracts of dill having strong anti-hyperlipidemic effects and improve the biological antioxidant status through reducing lipid peroxidation in liver of rats fed with high fat diet.

Ricardo et al. (2001) obtained that the levels of LDL and serum triglyceride decreases after using dill of hyperlipidemic mice. Weggemans and Trautwein (2003) indicated that dill contains phenolic compounds and flavonoids. In Hypercholesterolemic people, the presence of flavonoids cause increasing HDL-C and reducing LDL-C (Asgary et al., 2013). Yazdanparast and Bahramikia (2008) reported that there was significant decrease in atherosclerosis index and lipid profile in hyperlipidemic patients which treated with dill leaf powder. Hajhashemi and Abbasi (2008) confirmed that a significant decrease in the levels of triglycerides and cholesterol and a significant increase in HDL-c level of hyperlipidemic rats treated with dill. Carvone and tannin are available in dill, which effective in reducing appetite in animals and reduction of serum lipids (Yugarani et al., 1993).

\section{Conclusion}

The effect of fennel and dill seeds on serum lipid profile of rats feeding high fat diet was investigated. Serum glucose level, liver enzymes activities and kidney functions also were examined. The obtained results observed that fennel and dill seeds caused reduction on serum glucose level 
and significant decreased serum lipid profile. Treatment with fennel seeds or dill seeds at different levels caused improvement in kidney functions and liver enzymes activities compared to positive control group. Therefore, the present study recommended for using fennel and dill seeds powder as hypo-lipidemic herbs.

\section{References}

Abe, R. and Ohtani, K. (2013): An ethnobotanical study of medicinal plants and traditional therapies on Batan Island, the Philippines. J. Ethnopharmacol, 145(2): 554-65.

Abou El-Soud, N.; El-Laithy, N.; El-Saeed, G.; Wahby, M. S.; Khalil, M.; Morsy, F. and Shaffie, N. (2011): Antidiabetic Activities of Foeniculum Vulgare Mill. Essential Oil in Streptozotocin-Induced Diabetic Rats. acedonian Journal of Medical Sciences, 4(2):139-146.

Agarwal, R.; Gupta, S.K.; Agrawal, S.S.; Srivas-tava, S. and Saxena, R. (2008): Oculohypotensive effects of Foeniculum vulgare in experimental models of glaucoma. Indian J. Physiol. Pharmacol, 52: 77-83.

Ahmed, S.A.; Mohammed, A.A.; Abdullah, S.A. and Saadoon, A.H. (2013): Dill Effect on lipid profile of mice. Eng. Tech. J., 31 (4): 431-435.

AIN, (1993): American Institute of Nutrition Purified Diet for laboratory rodent, Final report. J. Nutrition., 123:1939-1951.

Allain, C. C; Richmond, N. and Rosechloy, P. (1974): Cholestrol enzymatic colorimetric test. Chem. Clin., 19 (20): 1350 - 1361.

Alsalame, H. A. A.; AL-Aameli, M. H.; Al-Taee, R. A. M. and Al-Bazii, W.G.M. (2018): Protective role of alchoholic extract of fennel seed in nephrotoxicity induced by cisplatin in male rabbits. Biochem. Cell. Arch. 18(1).

Asgary, S.; Rahimi, P.; Madani, H.; Mahzoni, P. and Kabiri, N. (2013): Preventive effect of hydroalcoholic extract of Carthamus tinctorius petal in appearance of type 1-diabetes mellitus in adult male rats. Int. J. Bioassys., 26(1):145-153. 
Ayman, M.; El-Din, G. and Al-Bekairi, A. M. (2006): Carvedilol, abeta adrenoceptor blocker with antioxidative potential, attenuates cisplatin-induced nephrotoxicity in rats. Journal of Applied Sciences Research 2(6): 331-335.

Barros, L.; Heleno, S.A.; Carvalho, A.M. and Ferreira, I.C. (2009): Systematic evaluation of the antioxidant potential of different parts of foeniculum vulgare mill. from Portugal. Food Chem. Toxicol., 47: 2458-2464.

Bekhradi, R. (2004): New treatment plant. $1^{\text {st }}$ Ed. Bekhradi pub; pp.61-73.

Campbell, J.A. (1963): Methodology of Protein Evaluation "RAG Nutr., Document R.10, Led.37.June meeting, New York.

Celik, I. and Isik, I. (2008): Determination of chemopreventive role of Foeniculum vulgare salvia officinal is infusion on trichloroacetic acid-induced increased serum marker enzymes lipid peroxidation antioxidative defense systems in rats Nat. Prod. Res., 22 (1): 66-75.

Choi, E. M. and Hwang J K (2004) Anti-inflammatory, analgesic and antioxidant activities of the fruit of Foeniculum vulgare. Fitoterapia, 75 (6): 557-565.

Choi, E.M. and Hwang, J.K. (2004): Antiinflammatory, anal-gesic and antioxidant activities of the fruit of foeniculum vulgare. Fitoterapia, 75: 557-565.

Conforti, F.; Statti, G; Uzunov, D. and Menichini, F. (2006): Compara-tive Chemical Composition and Antioxidant Activities of Wildand Cultivated Laurus nobilis L. Leaves and Foeniculumvulgare subsp.piperitum (Ucria) Coutinho Seeds. Biol. Pharm. Bull. 29(10):2056-2064.

Cosge, B.; Kiralan, M. and Gurbuz, B. (2008): Character-istics of fatty acids and essential oil from sweet fennel (Foeniculum vulgare Mill. var. dulce) and bitter fennel fruits (F. vulgare Mill. var. vulgare) growing in Turkey. Nat. Prod. Res., 22: 1011-1016.

Delaquis, P.J., Stanich, K., Girard, B., Mazza, G. (2002): Antimicrobial activity of individual and mixed fractions of dill, cilantro, coriander and eucalyptus essential oils. Int.J. Food Microbiol., 74:101-109. 
Delaram, M.; Kheiri, S. and Hodjati, M. R. (2011): Comparing the effects of echinophora-platyloba, fennel and placebo on pre-menstrual syndrome. J. Reprod. Infertil. 12 (3): 221-226.

Dongare, V.; Kulkarni, C.; Kondawar, M.; Magdum, C.; Haldavnekar, V. and Arvindekar, A. (2012): Inhibition of aldose reductase and anticataract action of trans-anethole isolated from Foeniculum vulgare Mill fruits. Food Chem., 132:385-390.

El Bardai, S.; Lyoussi, B.; Wibo, M. and Morel, N. (2001): Pharmacological evidence of hypotensive activity of Marrubium vulgare and Foeniculum vulgare in spontane-ously hypertensive rat. Clin. Exp. Hypertens, 23: 329- 343.

Fan, J.; Glass, M. A. and Chandhoke, P. S. (1999): Impact of ammonium chloride administration on a rat ethylene glycol urolithiasis model. Scanning Microscopy International, Chicago, 13(2-3): 299-306.

Fossati, P. and Prencipe, L. (1982): Serum triglycerides determined calorimetrically with an enzyme that produces hydrogen peroxide. Clin. Chem., 28:2077-2080.

Ghasemi Pirbalouti, A. (2009): Iranian medicinal and aromatic plants. Shahrekord: Islamic Azad University.

Hajhashemi, V. and Abbasi, N. (2008): Hypolipidemic activity of Anethum graveolens in rats. Phytother. Res., 22(3): 372-375.

Hegsted, D.; Mills, R. and Perkin, E. (1941): Salt mixture. J. Biol. Chem., 18:138-142.

Helal, E.G.E.; Eid, F.A.; Wahsh, A.M. and Ahmed, E. (2011): Effect of fennel (Foeniculum vulgare) on hyperlipidemic rats. Egypt J Hospital Med., 43:212-225.

Hexeberg, S.; Willumsen, N.; Rotevatn, S.; Hexeberg, E. and Berge, R.K. (1993): Cholesterol induced lipid accumulation in myocardial cells of rats. Cardiovasc. Res., 27: 442-446.

Hout, O. (1985): In: Interpretation of clinical laboratory tests-Siest,G.; Henny, J.; Schiele F, eds. london: Youn, D.S. Biomedical Puplication. 
Ibrahim, F.Y. and El- Khateeb, A.Y. (2013): Effect of herbal beverages of Foeniculum vulgare and Cymbopogon proximus on inhibition of calcium oxalate renal crystals formation in rats. Annals of Agricultural Science, 58(2): 221-229.

Jamshidi, E.; Ghalavand, A.; Sefidkon, F. and Goltaph, E. (2012): Effects of different nutrition systems (organic and chemical) on quantitative and qualitative characteristics of Fennel (Foeniculum valgare Mill.) under water deficit stress. Iran J. Med Aromat Plants, 28(2): 309-23.

Jana, S. and Shekhawat, G. (2010): Anethum graveolens: an indian traditional medicinal herb and spice. Pharmacognosy Reviews, 4(8):179-184.

Javidnia, K.; Dastgheib, L.; Mohammadi, S. and Nasiri, A. (2003): Antihirsutism activity of Fennel (fruits of Foeniculum vulgare) extract. A double-blind placebo controlled study. Phytomed, 10: 455458.

Joshi, H. and Parle, M. (2006): Cholinergic basis of memo-ry/strengthening effects of Foeniculum vulgare Linn. J. Med. Food, 9: 413-417.

Kaileh, M.; Berghe, W.V.; Boone, E.; Essawi, T. and Haegeman, G. (2007): Screening of indigenous Palestinian medicinal plants for potential antiinflammatory and cyto-toxic activity. J. Ethnopharmacol., 113: 510-516.

Kaur, G.U. and Arora, D.S. (2010): Bioactive potential of Anethum graveolens, Foeniculum vulgare and Trachys-permum ammi belonging to the family Umbelliferae-Current status. J. of Medic. Plant. Res., 4 (2): 087-094.

Kazemi, T.; Panahi, S. H.; Hossaini, F.M.; Darabi, M.; Kashanian, M. and Akbari, H. (2006): Effect of Dill pearl on serum lipids. Arak Univ. Med. Sci. J., 8 (3): 35-41.

Kojuri, J.; Vosoughi, A.R. and Akrami, M. (2007): Effects of Anethum graveolens and garlic on lipid profile in hyperlipidemic patients. Lipids Health Dis., 6(5): 1-5.

Lee. R. and Nieman, D. (1996): Nutrilional Assessment. 2 nd, Mosby, Missouri, USA. 
Liu, Y.P.; Xu, Y. and Gan, Z.M. (2009): The influence of the Foeniculum vulgare Mill on cytokine in hepatic fibrosis rats. J. Xinjiang Med. Univ., 6: 8.

Lopez-Virella, M.F. (1977). High density lipoprotein cholesterol by selective precipitin. Clin chem., 23: 882.

Malhotra, V.K. (2003):"Practical Biochemistry for Students" Fourth edition, Jaypee Brothers Medical Publishers (P) LTD, New Delhi.

Mannaa, F. A.; Ibrahim, N. A.; Ibrahim, S.S.; Abdel-Wahhab, K.G.; Hassan, N.S. and Mohammed, S.G. (2015): Preventive role of chamomile flowers and fennel seeds extracts against liver injury and oxidative stress induced by an immunosuppressant drug in rats. Hepatoma. .Res., 1:125-135.

Marzyieh, Z.; Alireza O.; Mahdavi1, R.; Nikbakhsh1, M.; Morteza, V.; Rezazadeh, H.; Delazar, A.; Nahar, L. and Satyajit, D. (2007): Assessment of anti-hyperlipidemic effect of Citrullus colocynthis "Brazilian J. of Pharmacognosy, 17 (4): 492-496.

Miguel, M.G.; Cruz, C.; Faleiro, L.; Simões, M.T.; Figueiredo, A.C.; Barroso, J.G. and Pedro, L.G.(2010): Foeniculum vulgare essential oils:chemical composition, antioxidant and antimicrobial activities. Nat. Prod. Commun. 5(2):319-328.

Modaress, N.V. and Asadipour, M. (2006): Comparison of the effectiveness of fennel and mefenamic acid on pain intensity in dysmenorrhoea. East Mediterr. Health J., 12: 423-427.

Monsefi, M. and Gramifar, F. (2013): Effects of aqueous fraction of Anethum graveolens L. (dill) extracts on fertility and terminal sugar of female rat's reproductive system. J. Birj. Univ. Med. Sci., 19 (4): 362- 375.

Monsefi, M., Gramifar, F. (2013): Effects of aqueous fraction of Anethum graveolens L. (dill) extracts on fertility and terminal sugar of female rat's reproductive system. J. Birjand. Univ. Med. Sci., 19 (4): 362375.

Moss, D. W. and Henderson A.R (1999): "Clinical enzymology. in: Burtis CA, Ashwood, E.R., editors. Tietz textbook of clinical chemistry. 3rd Ed. Philadephia: WB Saunders company; P. 617-721. 
Ostad, N., Soodi, M. and Sariffzadeh M. (2001): The effect of fennel essential oil on uterine contraction as a model for dysmenorrhoeal: pharmacology and toxicology study. J. Ethnopharmacol, 76: 299304.

Oulmouden, F.; Ghalim, N.; El Morhit, M.; Benomar, H.; Daoudi, E.M.; Amrani, S. (2014): Hypolipidemic and Anti- Atherogenic effect of methanol extract of Fennel (Foeniculum Vulgare) in hypercholesterolemic mice. Int. J. Sci. Knowl. , 3(1): 42-52.

Ozbek, H.; Ugras, S.; Dulger, H.; Bayram, I.; Tuncer, I.; Ozturk, G. and Ozturk, A. (2003): Hepatopro-tective effect of Foeniculum vulgare essential oil. Fitot-erapia, 74 (3): 317-319.

Qiang, F.; Yiming, A.; Shui-quan, W. and Zi-ming, G. (2011): Effects of foeniculum vulgare Mill on lipid peroxidation in rats with liver hepatic fibrosis. Prog. Mod. Biomed, 21: 13.

Rahimi, R. and Ardekani, M.R.S. (2013): Medicinal properties of Foeniculum vulgare Mill. In traditional Iranian medicine and modern phytotherapy. Chin. J. Integr. Med., 19(1): 73-9.

Reed, M.J.; Meszaros, K.; Entes, L.J.; Claypool, M.D.; Pinkett, J.G. and Gadbois, T.M. (2000): A new rat model of type 2 diabetes: the fatfed, streptozotocin -treated rat. Metabolism, 49: 1390-1394.

Ricardo, K.F.S.; Aliveria, T.T.D. and Nagem, T.J. (2001): Effect of flavonoids morin, quercetin and nicotinic acid on lipid metabolism of rats experimentally fed with triton. Brazilian Arch. Biol. Tech., 44(3): $1-5$.

Rojas, E.; Herrera, A.L.; Poirier, L.A. and Ostrosky -Wegman, P. (1999): Are metals dietary carcinogens? Mutat. Res., 44: 157 - 181.

Setorki, M.; Shahinfard, N.; Ansari, R.; Forouzandeh, Z.; Asgharzadeh, S. and Rafieian, K.M. (2013): Comparison between the Effect of Hydroalchohlic Extract of Dill and Statins on Lipid Profile. J. Kerman. Univ. Med Sci., 20(2): 158-168. 
Tang, S.Y. and Halliwell, B. (2010): Medicinal plants and antioxidants: what do we learn from cell culture and Caenorhabditis elegans studies? Biochem. Biophys. Res. Commun., 394(1): 1-5.

Tognolini, M.; Ballabeni, V.; Bertoni, S.; Bruni, R.; Impicciatore, M. and Barocelli, E. (2007): Protective effect of Foeniculum vulgare essential oil and anethole in an experimental model of thrombosis. Pharmacol. Res., 56: 254-260.

Valko, M.; Leibfritz, D.; Moncol, J.; Cronin, M.T.; Mazur, M. and Telser, J. (2007): Free radicals and antioxidants in normal physiological functions and human disease. Int. J. Biochem. Cell Biol., 39: 44-84.

Weggemans, R.M. and Trautwein, E.A. (2003): Relation between soyassociated isoflavones and LDL and HDL cholesterol concentrations in humans: a meta-analysis. European J. Clin.Nutr., 57: 940-946.

Yazdanparast, R. and Alavi, M. (2000): Antihyperlipidaemic and antihypercholesterolaemic effects of Anethum graveolens leaves after the removal of furocoumarins. Cytobios., 105(410):185-191.

Yazdanparast, R. and Alavi, M. (2001): Antihyperlipidaemic and antihypercholesterolaemic effects of Anethum graveolens leaves after the removal of furocoumarins. Cytobios 105:185-191.

Yazdanparast, R. and Bahramikia, S. (2007): Improvement of liver antioxidant status in hypercholesterolamic rats treated with A.graveolens extracts. Pharmacology online, 3:88-94.

Yazdanparast, R. and Bahramikia, S. (2008): Evaluation of the effect of Anethum graveolens L. crude extracts on serum lipids and lipoproteins profiles in hypercholesterolaemic rats. DARU Journal of Pharmaceutical Sciences, 16 (2):88-94.

Yousofvand, N. and Soltany, A. (2015): Effects of Hydroalcoholic Extract of Dill (Anethum graveolens) on the serum levels of blood lipids (cholesterol, Triglycerides, LDL and HDL) in male NMRI mice. Journal of Pharmaceutical, Chemical and Biological Sciences, 3(1):114-121. 
Yugarani, T.; Tan, B.K.H. and Das, N.P. (1993): The effects of tannic acid on serum and liver lipids of RAIF and RICO rats fed on high-fat diet. Comp. Biochem. Physiol., 104 (2): 339-343.

Zheng, G.; Kenney, P.M. and Lam, L.K.T. (1992): Anethofuran, Carvone and Limonene: potential cancer chemopreventive agents from dill weed oil and caraway oil. Planta Med., 58:339-341. 


\title{
Wafaa A. Refaat and Doaa E. El-Nassag
}

\section{تأثير بذور الشمر والثبت على صورة دهون سبرم الدم في الفئران}

\section{التي يتم تغذيتها على وجبات عالية الدهون}

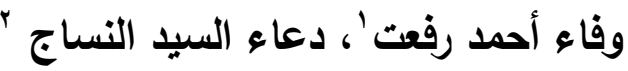

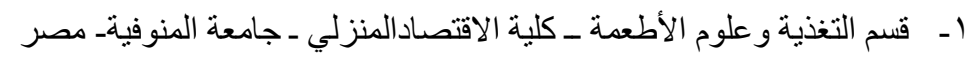

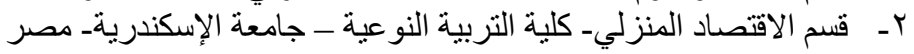

\begin{abstract}
المستخلص
بذور الثبت والثمر نباتات عشبية تزرع في مناطق مختلفة حول العالم ولها العديد من الآثار
\end{abstract} العلاجية كمضادة للالتهابات والفيروسات والجراثيم ومضادة لمرض السكر وخافضة للدهون. لذلك ، أجريت هذه الدراسة لتقبيم تأثنرمسحوق بذورالثمروالثبت على صورة صورة دهون سيرم الدم في الفئران التي بتم تغذيتها على وجبات عالية الدهون. حيث استخدم ، ع فأر من ذكور فئران الألبينو

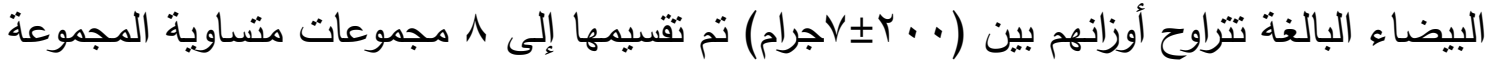

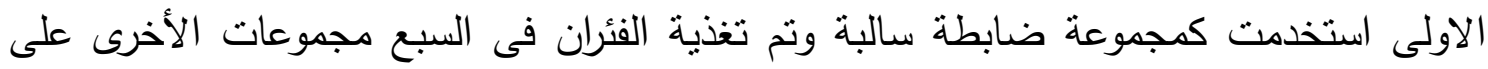

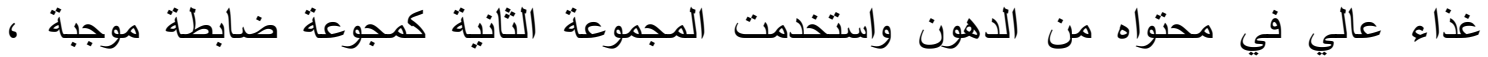

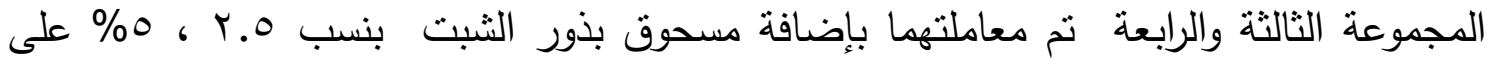

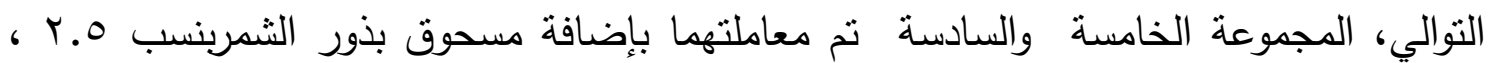

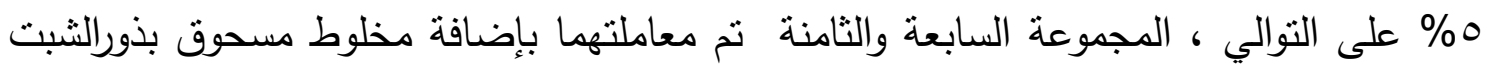

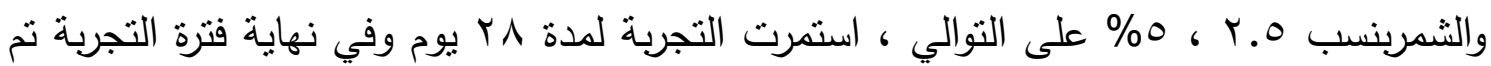
ذبح الفئران وأخذت عينات من الدم لقياس مستوى الجلوكوز ، نشاط انزيمات الكبد ، وظائف الكلى

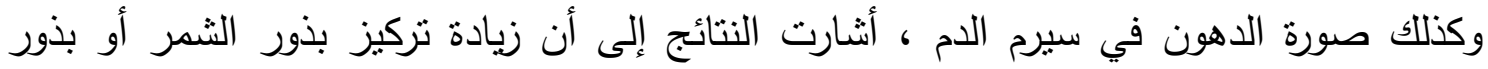

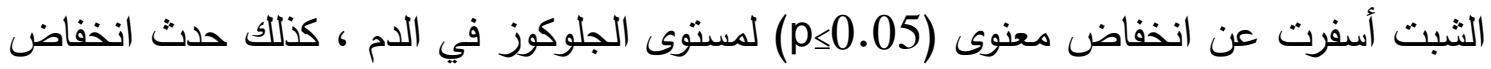

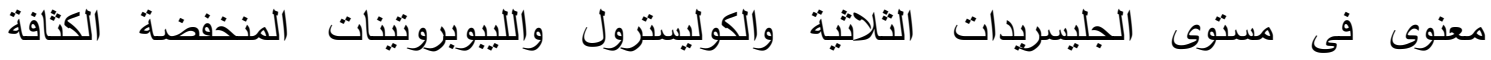

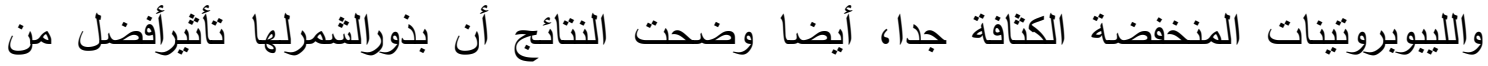

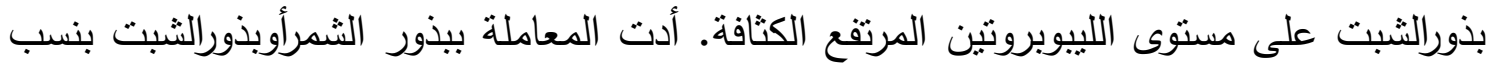
مختلفة الى انخفاض معنوى (p<0.05) في حمض اليوريك ؛ مستويات الكرياتينين واليوريا مقارنة

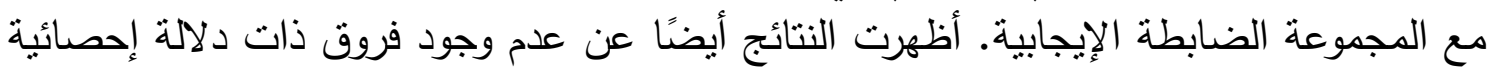

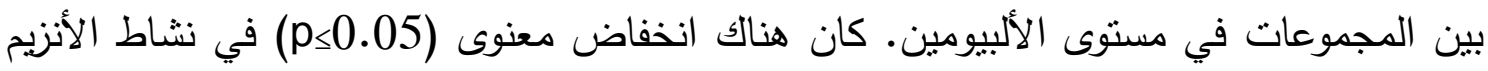

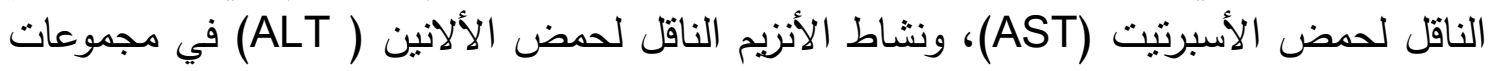

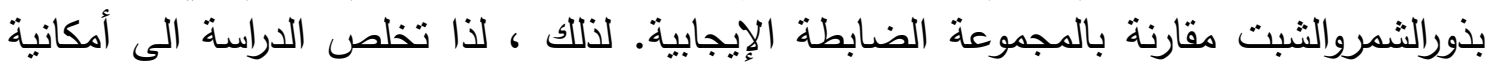
إدخال مسحوق بذورالثمروالثبت في الأطعمة والمشروبات اليومية كأعثاب خافضة لإنهابهة لدهون الدم.

الكلمات المفتاحية: الثبت، الثمر ، البذور، ، صورة دهون الدم، البيومين، نشاط انزبمات الكبد. 